\title{
THE DEVELOPMENT OF COMMUNICATION SKILLS OF STUDENTS OF SECONDARY SCHOOL AS A COMPONENT OF THEIR LEADERSHIP POTENTIAL
}

\author{
Vasyl Kovalchuk \\ Oleksandr Dovzhenko Hlukhiv National Pedagogical University, Ukraine
}

Tetiana Iermak

Institute of Pedagogy of the National Academy of Educational Sciences of Ukraine, Ukraine

\begin{abstract}
The professional effectiveness depends on many factors, and good verbal communication skills, as a basis for productive relationships, mutual understanding and realization of goals and objectives of professional effectiveness as a way of self-improvement, self-realization and overcoming personal crises, are of great importance. The communication skills are basic ones in forming a leader. The concept of "communication skills" in the article is defined as the ability to communicate effectively, the ability to understand what the interlocutor means and be understood by them, the ability to negotiate, achieve their goals through communication. This type of skills performs many important functions in the personal development: provides psychological comfort, allows you to organize joint activities, meets the natural human need for communication, helps to assert itself, socially realize themselves. The success of a person in life depends on the ability to communicate. The personal success depends on the communication skills. Communication skills are important both for the social realization of the individual and for psychological life satisfaction. The article substantiates the problem of developing students' communication skills. The pedagogical conditions for the development of students' communication skills, including: creation of a favorable educational environment, application of a personality-oriented approach to learning, modeling of real professional communication conditions, are identified and substantiated. Informationcommunicative, regulatory-communicative and affective-communicative skills are singled out. To determine the level of development of these skills, we used the method of determining communicative levels of communicative and organizational tendencies: very low, low, medium, high. The study involved 196 students and 30 teachers of the educational complex of lyceum №157 in Kyiv.
\end{abstract}

Keywords: communication skills, communication, leader skills, leader, student of secondary school.

\section{Introduction}

The development of leadership potential of students is an urgent problem of modern education, because it is the school where active formation of values, civic position, and establishing life priorities of young people take place. 
Today's society needs young people who will make decisions independently, be responsible for them, put forward and implement social initiatives developing leadership potential.

For the education of leaders of the new generation, the problem of developing leadership skills becomes more timely than ever.

Since communication is the basis for building relationships among people, formation of communication skills becomes especially important. The leader needs them to build teamwork to achieve the goal. Such skills are the main tool of the leader, which Modern education concept relies much prominence on preparing a student for being the finest professional in a specific platform. Effective communication is an essential part of a professional life no matter in what field you are. Students with effective communication skills will be more probably to contribute to class discussions, will ultimately achieve more from their experience in class, and will be more productive members in group projects. Allows them to interact effectively with people and influence followers (Singh, 2020). Communication skills are recognized as key skills of the 21st century, so the role of schools in creating the necessary conditions for their formation is growing. Communication is key in the classroom: successful teaching is generally considered to require only 50\% knowledge to $50 \%$ communication skills (Sword, 2020). While in school, children should actively develop communication skills in all lessons, as well as during extracurricular activities at school and at home. Such skills are formed under the influence of the family, friends and the media.

However, some essential aspects of communication skills are often overlooked, for instance, the ability to listen and hear, understand, avoid misunderstandings, overcome uncertainty in communication, meet new people, ask for a favor or help. This is particularly important for Generation Z. According to the New York Times children between the ages of 8 and 10 years spend 8 hours a day on screens. This figure goes up to 11 hours for older students, so it's really no surprise our students' communication skills are lacking. Sometimes kids have few adult role models to show them how to be good listeners and have productive, healthy conversations. Many students have speech or other communication disorders that may impede their ability to speak and listen well (Brody, 2015).

A student possessing these skills will be more effective in the future.

Developed communication skills help to negotiate effectively, speak in front of an audience, establish contact with the interlocutor, and express themselves. Communication skills determine the ability to communicate effectively and the ability to understand the interlocutor, to present themselves and negotiate. They provide the individual with psychological comfort, help to 
organize collaboration, as well as self-affirmation and self-realization in society. Communication skills are required in every profession.

Communication is a two-way path which signifies that there is a communicator and also the one whom something is being communicated. The communication takes place only when information is shared amid two individuals. Effective communication can help to build and encourage a safe learning atmosphere where students can learn, prosper, and thrive. The significance of building good communication at a young age is critical in a child's growth and future learning. Communication skills that students learn at school are completely vital and transferable across all aspects of life (Singh, 2020).

Analysis of the scientific literature has enabled us to identify key concepts. In particular, skills are seen as automated actions that are formed by repetition and are characterized by a high degree of acquisition, and do not require guidance and control (Radul, 2004).

Communicative skills are automated conscious actions that help to quickly reflect communicative situations in the mind of an individual, and determine the success of perception, understanding of the world and the corresponding impact on it in the communication process (Burman, 2000, Khomiak, 2010).

Communicative skills are the levels of mastering communicative actions in terms of assessment of the communicative situation; perception, production and transmission of information, establishment of contact, planning, organization and ensuring the efficiency of communication, which, in turn, leads to the effective implementation of educational goals and personal interests.

According to A. Leontev, a communicative skill is the ability to differentiate the use of different skills or their combination to achieve different communicative goals. The scientist identifies the following communication skills: the ability to manage behavior (volitional qualities); observation, flexibility (quality of attention); the ability to understand facial expressions, to understand and adequately model the personality of the interlocutor, their mental state according to external evidence (ability of social perception); the ability to optimally build their speech in terms of psychology (the ability of speech and non-speech contact); ability to comprehend, systematize and transfer information (gnostic skills) (Leontev, 2002).

There are different classifications of communication skills. Let us consider one of them:

Information and communication skills allow a person to establish communication freely, support the interlocutor, use verbal and nonverbal communication methods. Regulatory and communicative skills ensure the coherence of actions and words to the needs of the interlocutor, as well as feelings of trust and support, evaluation and feedback. Affective-communicative 
skills involve the ability to convey personal feelings and interests to the interlocutor, understand his emotional behavior, be sensitive and to show empathy and care.

Communication skills allow people to succeed in work and career, control difficult situations, deal with conflicts, and negotiate successfully (Komunikatyvni navychky, 2019).

\section{Purpose and Tasks of Research}

The main purpose of the article is to study the problem of development of communication skills as a component of their leadership potential, and to identify the state of their formation in secondary students. Achieving the main goal involves the following task:

1. Define the essence of the concept of communication skills and their classification.

2. Identify and justify the pedagogical conditions for the development of communication skills of students in the educational process of the school.

3. Experimentally identify the level of formation of organizational and communication skills.

\section{Methodology and Research Results}

The Ajay Singh offers ways to improve effective communication skills in students: motivate students to initiate and engage in conversation; create a safe ambiance; active listening; more teamwork; allow students to share opinions; positive feedback (Singh, 2020). Teachers and parents must assume the role demanded by the child and gently guide them in the improvement of their communication abilities. We see the potential in the modeling of language, roleplaying and involving the parent in the classroom to elicit and develop the communication and language skills of students. Teachers are in the perfect position to create an environment that supports communication skills in learners.

Lee Watanabe-Crockett presents 5 ways of improving your learners' communication skills: encourage the child to initiate and engage in conversation; model active listening and reflection; conference with parents or caregivers; role-play in the classroom; allow students to share opinions and vote in the classroom (Watanabe-Crockett, 2019).

Favorable conditions must be created for the development of students' communication skills in the school educational process at school. We analyzed the scientific literature, conducted a brainstorming session among school teachers to identify pedagogical conditions for the development of 
communication skills. The experiment involved 30 experts - different subject teachers. A list of 10 conditions which according to teachers will promote the development of communication skills was created. However, to achieve this goal, we decided to dwell on three conditions. The experts were asked to rank the selected conditions according to the degree of importance and opportunity of their implementation in the educational process.

The first pedagogical condition is creation of a favorable educational environment. In the modern educational paradigm the concept of humanization of the environment is promising.

This can be achieved by creating favorable conditions for the subjects of the pedagogical process, which gives a child meaning in life, carries an inexhaustible source of motivation, inspiration, creativity; ensures unity of teacher and students on the basis of spiritual affinity of mutual understanding, interaction and cooperation.

The atmosphere of a favorable environment of the educational institution should be based on trust, empathy, and positivity, which determine the perspective of success for both the whole educational institution and for all subjects of the pedagogical process.

The environment must change, transform in accordance with the sociopedagogical conditions, actualize the creative potential of a student, must take into account their system of values, needs, reasons and inner motivations.

Scientists are convinced of the influence of the environment as an important pedagogical tool that allows to solve complex problems, develop new educational content, introduce modern forms, methods and technologies of personal development.

A favorable educational environment is the environment in which the interaction of all participants of the pedagogical process results in their spiritual, intellectual, moral, aesthetic, and physical mutual enrichment. This environment promotes the development of creative potential, self-realization of the individual, forms readiness for personal self-improvement, ensures realization of co-creation within the humanistic paradigm (Kovalchuk, 2011).

Usually, this type of environment is integrated and includes other microenvironments: cognitive, psychological, scientific and methodological, social, cultural and aesthetic, physical, sanitary and hygienic, and electronic. Such an environment facilitates students' adaptation to school life and helps develop the necessary qualities.

The role of the teacher is to create and maintain a favorable learning atmosphere that has a positive effect on the student's motivation, enhances the development of their creativity and cognition. However, each participant of the educational process should make their contribution. 
The Indicators of a favorable educational environment are: joint activities; common goals; satisfaction from being part of the team; constant feedback; taking into account the characteristics and needs of each participant; awareness of goals and procedures; good psychological microclimate and emotional satisfaction; democratic management style; good material base.

Being in a favorable educational environment a person develops individuality. The current situation in the country requires understanding of the management of educational institutions and the introduction of new approaches to creating the enabling environment.

The second pedagogical condition for the development of students' communication skills is the application of a personality-oriented approach to learning (Romanovskyi, 2009).

Traditional teaching styles and methods are outdated and do not allow young people to develop their abilities. The solution to this problem is that educators need to select and apply teaching methods that will help students better acquire knowledge and develop creative thinking and behavior. Learning is effective when the student changes their attitude or behavior for the better (Kovalchuk, 2011).

The organization of the educational process should: take into account the needs of the learner; conditions for physical and emotional development; opportunities for cooperation and collaboration between the student and the teacher; opportunities for each student to achieve the level of success, education and development; individualization of training; opportunities for selfknowledge, self-development, self-learning; the applicant's involvement in defining the purpose of training, planning of educational activities, and reflection.

The effectiveness of the learner's education depends on the motivation to acquire knowledge. Positive motivation depends on the teacher in formation of the need for learning. Personality-oriented learning produces psychological freedom of the learner, as well as a system of values. The student can evaluate their strengths and abilities, as well as develop their own creative potential.

Dialogic pedagogy should be based on the principles of equality of personal positions, openness and trust, and considering the views of each participant.

The teacher, in turn, must teach the student to be critical of themselves and their actions, to motivate and stimulate, to make the student a co-author of the educational process, to create favorable conditions for effective acquisition of knowledge. Technologies of personality-oriented education, contribute to the creation of conditions for development of a personality. These include training technologies (professional-behavioral training, reflexivity training), dialogic 
teaching methods (group discussions, situation analysis); game technologies (dialogue, role and business games) (Savichev, 2010).

Their use should be based on a number of principles. This is in particular: the principle of personal approach, in which the teacher and the student are likeminded. Since human communication begins with establishing contact, primary communicative adaptation and focusing on the interlocutor are extremely important. Under such conditions, internal tension and complexes disappear, and mutual understanding appears. Also, occurs the principle of situationality which provides selection and organization of material on the basis of situations and problems of communication in the development of communication skills, because motivation of communication arises only in situations that are important for interlocutors. Another principle is modeling, according to which the content of learning should be represented not by topics but by problems. Finally, the principle of two-way educational communication, which consists in a clear division of functions between the teacher and the students.

The teacher manages communication in order to form, drill and consolidate the skills and abilities of speech; students focus primarily on communication, because by means of speech they can go beyond learning situations; the principle of a differentiated approach to the formation of groups. The initial level of communication skills should be considered in the formation of study groups; the principle of active learning, which manifests in external and internal activity of the student. For this purpose it is necessary to increase the amount of individual, group and collective forms of education and to reduce traditional frontal work, in which the teacher is an active participant; the principle of group interaction, which involves disclosure of the individuality of each student through communication - for this purpose the group should be dominated by such psychological climate that will effectively identify and reveal the capabilities of each student.

The third pedagogical condition for the development of communication skills is the modeling of real communication conditions.

This involves a real reproduction of communicative situations in which students will learn to communicate effectively using their own experience.

Modeling real professional situations will help students experience the responsibility for their words and deeds, will teach them to understand and interact with colleagues, and choose the right language tools for formulating and expressing opinions (Romanovskyi, 2009).

Modeling communication situations creates the conditions for the transformation of the student from the object to the active agent of the pedagogical process, and the search for ways to solve the problem contributes to the development of important professional qualities. 
Modeling communication situations and involving students in them contributes to gaining successful experience in solving problems. This method helps to enhance motivation and values, allows you to make sure of their capabilities and abilities and as a result to improve them.

Different game methods are used to model such situations, for example plot-role and business games, the characteristic feature of which is the improvisational acting by the participants of the given problem situation of professional interaction, during which they play the roles of different characters. In this case, the subject of further discussion is not the situations themselves, but the game interaction of the participants: their forms and means of communication, ways to resolve problem situations and conflicts, their effectiveness, social and interpersonal roles, etc. The game activates children's desire to contact each other and the teacher, creates equal conditions in conversation, and destroys the traditional barrier of insecurity. In games, students master such elements of communication as the ability to start and maintain a conversation, interrupt the interlocutor, agree with his suggestion or reject it at the appropriate moment, listen to the interlocutor consciously, ask questions, etc.

The use of game methods in the process of developing communication skills is extremely productive.

Modeling communication situations allows you to anticipate the difficulties that students may face in life, and identify ways to overcome them.

Modeling of pedagogical situations should be carried out in a certain sequence, should correspond to logic of formation of the student's need for communication and to a complex of mental operations which are necessary for the solutions of these situations. The simulated situations should reflect real problems.

Such communicative conditions can be created if we have certain techniques, prediction of relevant social and personal factors, and the behavior of participants. These skills include:

1. Management of the relationship process, which involves positive positioning of yourself with the interlocutor, positive feedback, focusing on yourself and important things, emotional control during transmission of information, creating communication links, emphasizing, controlling and keeping in mind the relationship between interlocutors.

2. Openness and communicativeness in relations with students.

3. Reassignment of communication to the spiritual or personal level.

4. Management of suggestive states (opinion of others, stereotypes), pedagogical optimism (avoid jumping to conclusions). 
5. Identify "danger zones" for communication: when students get annoyed, become aggressive, the ability to be the student's shoes and understand his reaction: the ability to show tolerance, respect in relations with students; successfully interact with students who have other values due to individual or cultural and ethical characteristics.

6. Ability to relieve nervous tension (ability to relax, sit freely).

7. Mood management and ability to influence the mood of students positively.

To determine the level of the studied skill formation, we used the test «Diagnosis of communicative and organizational propensities» (Fetiskin, Kozlov \& Manujlov, 2002). The questionnaire contains 40 questions. The total number of respondents who took part in the survey was 196 students from grades 9-11 aged 14-16. The maximum number of points separately for each parameter is 20. Points are calculated separately for communication and separately for organizational propensities using a key for data processing. One point is assigned for each answer «yes» or «no» for statements that coincide with those specified in the key separately for the respective propensities. Five levels of communicative and organizational propensities have been experimentally established. The sum of points 1-4 indicates the level as very low, 5-8 - low, 9-12 - average, 13-16 - high, 17-20 - the highest. According to the results of the survey, the following data were obtained (Fig. 1): very low $14.8 \%$, low $-9.2 \%$, average $-33.10 \%$, high $-42,9 \%$, the highest level is not detected.

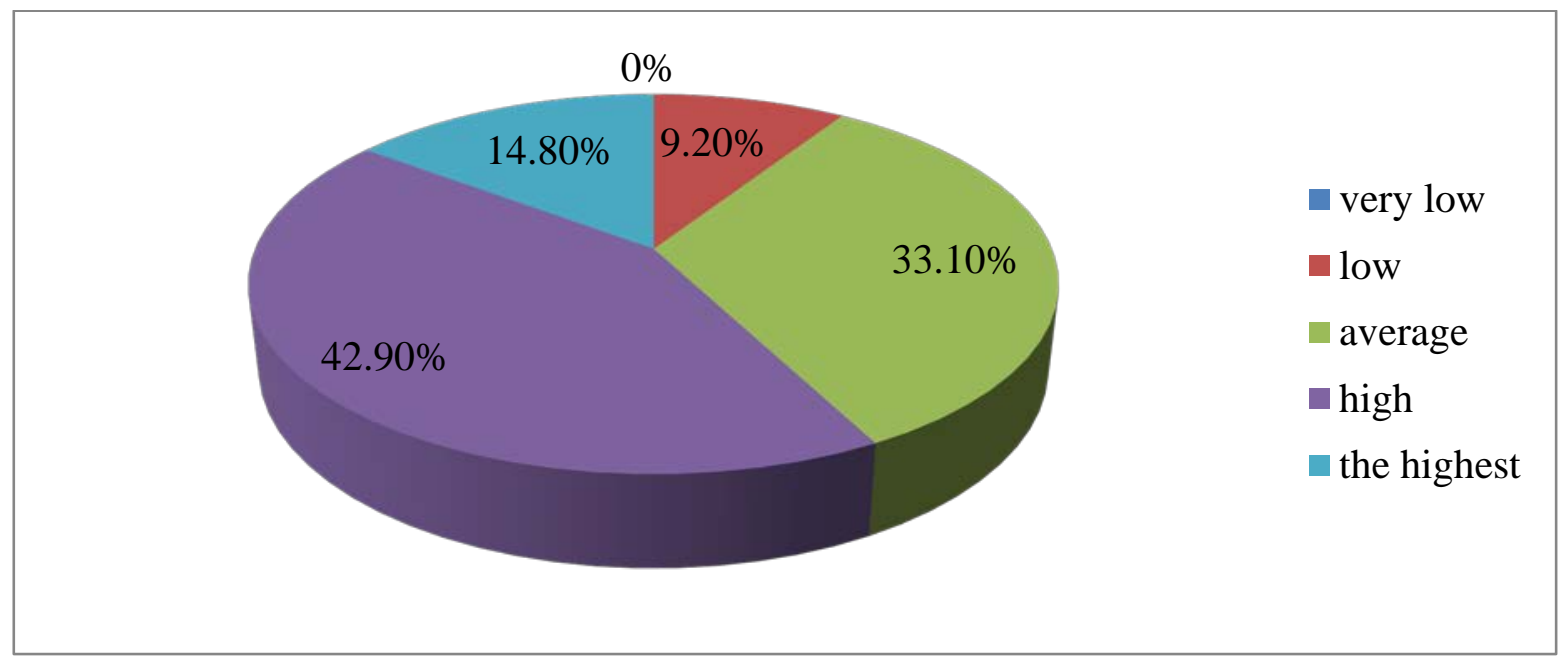

Figure 1 The Results of the Study of Identifying Communication Skills

Score 1-8 - indicates a low level of communication and organizational propensities. 
Score 9-16 - indicates communicative and organizational propensities at a level below average. Such students do not seek to communicate, preferring to spend time on their own. In a new company or team they feel awkward and experience difficulties in establishing contact with people. They do not stand their grounds, and it is hard for them to deal with insults. Rarely do they show initiative, and they avoid making independent decisions.

Score 17-24 - characterizes the average level of manifestation of communicative and organizational propensities. Such individuals seek contact with people, stand their grounds, but the potential of their propensities is not very stable. They need further educational work on the formation and development of these personality traits.

Score 25-32 - indicates a high level of communicative and organizational propensities. People feel relaxed in new circumstances, quickly find friends, seek to expand the circle of their acquaintances, help relatives and friends, show initiative in communication, and are able to make decisions in difficult and unusual situations.

Score 33-40 - the highest level of communicative and organizational propensities. This indicates that such people have a need for communication and organizational activities. They understand quickly what to do in difficult situations, feel comfortable in a new team, and take initiative. Such people make independent decisions. They defend their opinion and seek to make their decisions. They like to organize games, various events. and demonstrate persistence and inspiration in the activities they participate.

The results of a study to identify communication skills showed that (Fig. 2): very low $-2 \%$, low $-14.0 \%$, average $-49 \%$, high $-31 \%$, the highest $4 \%$.

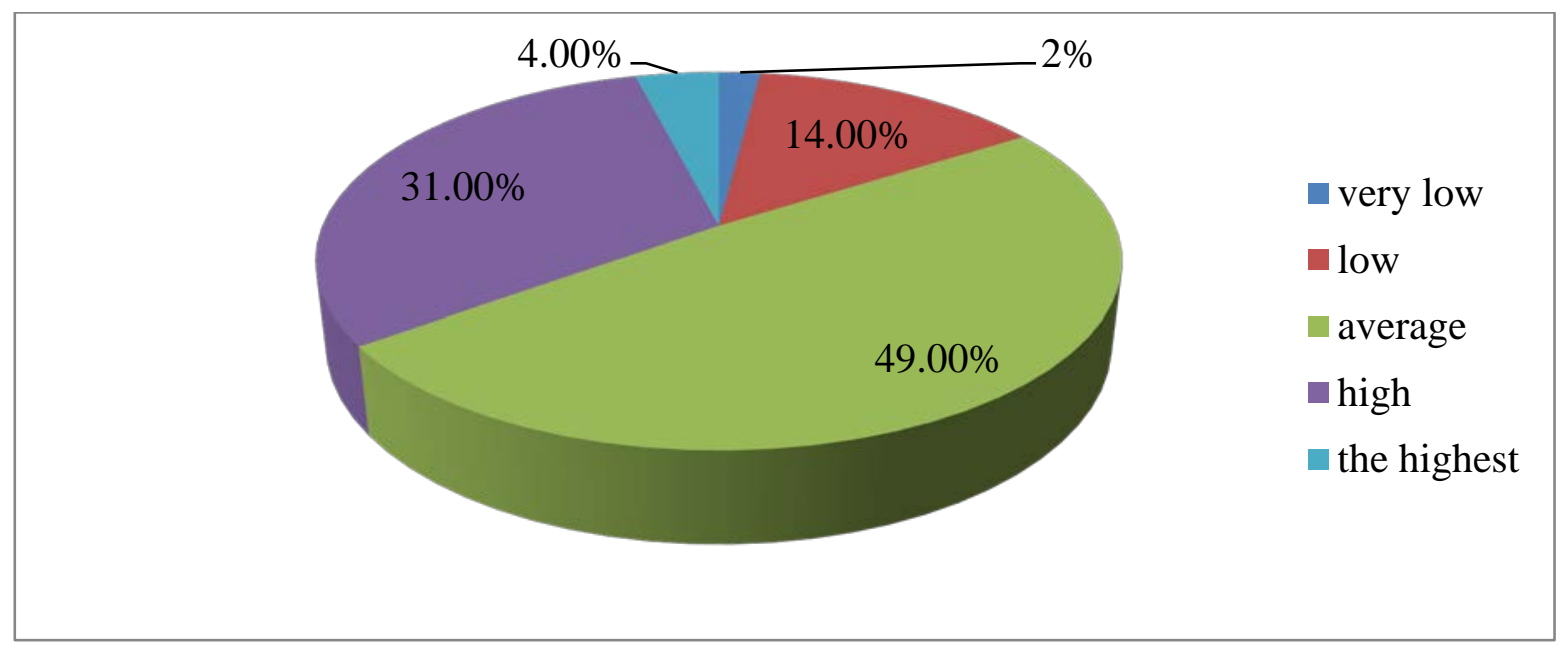

Figure 2 The Results of the Study of Identifying Organizational Skills 
Among the questions about communicative propensities, the largest number of respondents answered positively to the question «Is it easy for you to establish contacts with people who are older than you?» (yes) and «Do you want to limit the circle of your acquaintances?» (no) - 80.1\% and $82.1 \%$, respectively, which indicates a lack of ageism and openness of the majority of respondents.

Among the questions about organizational propensities, the largest number of respondents answered positively to the question «Is it always difficult for you to deal with a critical situation?» (no) and «Is it true that you rarely try to prove yourself?» (no) $-82.7 \%$ and $84.2 \%$ respectively.

At the same time, only $42.7 \%$ of respondents answered positively to the question «Do you feel relaxed when you get into an unfamiliar team?» and $44.9 \%$ «Do you like being among people all the time?», which shows one of the lowest results among communication propensities.

We see even lower rates for questions about organizational propensities, both questions are related to community service: «Do you participate in community service at school?» (yes) $33.2 \%$ and «Do you like doing community service?» (yes) 35.2\%.

The results of the survey showed the highest percentages in terms of medium and high level of development of communicative and organizational propensities and lack of a very low level. This also confirms the presence of leadership potential in students.

\section{Conclusion}

Communicative skills are an integrated feature of the individual, characterized by mastery of certain methods and techniques by which partners enter into a situation of communication, establish and maintain contacts and purposeful relationships, and achieve the goal. Communication skills are a necessary component of a person's leadership potential.

Developed communication skills will help to take into account the emotional and psychological influences of the environment, the inner circle, listen and hear others, empathize, be open in communication, provide feedback in communication, respond adequately to the actions of other participants and the communication situation in general, to defend their rights during communication, etc.

Diagnosis of students' communication skills will help the teacher to assess the current level of development and consider the ways for further improvements. 
Kovalchuk \& Iermak, 2021. The Development of Communication Skills of Students of Secondary School as a Component of Their Leadership Potential

\section{References}

Brody, J. E.(2015). Screen Addiction is Taking a Toll on Children. The New York Times, 6 July 2015. Retrieved from www.well.blogs.ntyimes/2015/07/06/screen-addiction-istaking-a-toll-on-children/.

Burman, L. (2000). Dydaktychni umovy formuvannia dialohichnykh umin u studentiv vyshchykh navchalnykh pedahohichnykh zakladiv: avtoref. dys. ... kand. ped. nauk: 13.00.04.

Fetiskin, N., Kozlov, V., Manujlov, G. (2002). Diagnostika kommunikativnyh i organizatorskih sklonnostej (KOS-2). Social'no-psihologicheskaja diagnostika razvitija lichnosti i malyh grupp. Moskva. 263-265.

Khomiak, A. (2010). Pedahohichni tekhnolohii formuvannia komunkatyvnoi kompetentnosti starshoklasnykiv u protsesi vyvchennia predmetiv humanitarnoho tsyklu. Avtoref. dys. ... kand. ped. nauk.

Komunikatyvni navychky. (2019). Retrieved from https://zhyvoedelo.com/ua/news/ kommunikativnye-navyki

Kovalchuk, V. (2011). Tekhnolohiia navchannia doroslykh na osnovi osobystisno oriientovanoho pidkhodu: treninh. Kyiv: Shkilnyi svit, 128 p.

Kovalchuk, V. (2011). Stvorennia spryiatlyvoho navchalnoho seredovyshcha: Treninhy. Kyiv: Shkilnyi svit.

Leontev, A. (2002). Psihologija obshhenija. - 2-e izd. Moskva: Akademija.

Radul,V. (2004). Sotsioloho-pedahohichnyi slovnyk. Kyiv: «EkOb».

Romanovskyi, O. (2009). Pedahohichni umovy formuvannia komunikatyvnoi kompetentnosti maibutnikh inzheneriv. Teoriia i praktyka upravlinnia sotsialnymy systemamy: filosofiia, psykholohiia, pedahohika, sotsiolohiia, 3, 86-93.

Savichev, S. (2010). Problema razvitija kommunikativnoj kompetentnosti studentov vysshej shkoly. Izvestija Samarskogo nauchnogo centra Rossijskoj akademii nauk, Tom 12, 5, 78-80.

Singh, A. (2020). How To Improve Effective Communication Skills In Students. The Asian School. Retrieved from https://www.theasianschool.net/blog/how-to-improve-effectivecommunication-skills-in-students/

Sword, R. (2020). Effective Communication in the Classroom: Skills for Teachers. HUB. Retrieved from https://www.highspeedtraining.co.uk/hub/communication-skills-forteachers/.

Watanabe-Crockett, Lee. (2019). 5 Quick Ways of Improving Your Learners' Communication Skills. Global Digital Citizen Foundation, February, 2019. Retrieved from https://globaldigitalcitizen.org/improving-your-learners-communication-skills. 